\title{
Development of Interactive Compact Disk Learning Media with Caring For Living Things Theme
}

\author{
Eges Triwahyuni ${ }^{1}$, I Kadek Suartama ${ }^{2}$ \\ 1Universitas PGRI Argopuro Jember, Indonesia \\ 2Universitas Pendidikan Ganesha, Indonesia \\ eges.triwahyuni@gmail.com,ik-suartama@undiksha.ac.id
}

\begin{tabular}{ll}
\hline Article History & Received : June $7^{\text {th }} 2021$ \\
& Revision : July $19^{\text {th }} 2021$ \\
& Publication : Sept $30^{\text {th }} 2021$ \\
\hline
\end{tabular}

\begin{abstract}
This research aims to design and make learning that is packed with Intractif CD to facilitate applying teachers to learning activities with the theme III caring for living creatures of animal and plant subtema in my home environment for grade IV elementary school odd semester. research place in Seskolah Dasar Negara 1 Kandang Kapongan Situbondo Regency with a total of 15 learners. With this research using the ADDIE development model (Analysis, Desagn, Develop, Implement,and Evaluate)bysourced on the results of research, it can be concluded that educational media packaged by Intractif CD with the theme of caring for living things meet the eligibility criteria with the field of media experts obtaining a value of $89.91 \%$ listed among the qualifications is very feasible and validation of the field of media experts obtained a value of $86.95 \%$ listed qualifications are very feasible, and the renponden in the feasibility and effectiveness of obtaining a value of $86.69 \%$ and vice versa effectiveness while effectiveness obtained a value of $85.90 \%$.
\end{abstract}

Keywords: Learning Media, Interactive CD, IV Elementary Students

\section{INTRODUCTION}

Education is a conscious effort planned by god almighty creatures can realize the activities and learning process of learners to develop the potential of each individual learner who has spiritual, self-control, intektul, akhaqul karima and skills for himself community, nation and state. Educational efforts are essentially to prepare for the opposition to globalization to come.

Alpha generation for the nation's successor to have a high level of ability and in accordance with the development of science and technology. Especially in preparing students to be subjects who increasingly play a role to display their independent, creative, and professional ability in their respective fields. 
Educational media is a vehicle and the delivery of information or educational messages to learners. With the service of learners in the learning process, to be able to help teachers in enhancing learning and educating learners. Media studied continuously experienced very rapid growth along with the growth of technology and information. (Kadek Suartama et al. 2020). Is one example of using the medium of learning in the process of learning activities.

Learning media to design a learning content in the learning process (Fajarisman, Asri Widiatsih 2020) packaged in one software to be practical, effective and efficient to operate it during learning activities. An education must have creativity in designing content or learning mediafor students to be passionate about learning and enthusiastic to followlearning.

In the process of media learning is very used the goal is to make it easier for teachers to convey material to learners,providing good quality of learning and productive in learning time. The problem most of today that often occurs during learning in the classroom isthatmost teachers who deliver lessons to elementary school students are still in using conventional methods because the educational information presented in the Constitution sometimes makes a child less interested, because the educational media displayed by the Conventional is only in the form of explaining and recording Often mentioned summarizing this makes students follow learning that makes students feel bosan timelearning activities in school.

SD Negeri 1 Kandang Situbondo is a public school in kapongan sub-district that still uses the learning process of conventional media that makes learners less together in the process of learningin school. Learners cuma see the reading text and the teacher describes onthe black warn a boardlike the picture below.

This can cause a student to feel saturated and attention to learning also the conclusion candecrease. while in the school there are facilities and infrastructure that support to provide the convenience of a teacher to make the learning media more interesting contained in the learning media there are images, videos and evaluations to make it easier for a teacher to provide content in learning that has been packed on the Intractif CD.

Inaddition to educational activities at the elementary school level, researchers design learning media packaged into Intractif CDs is one of the educational delivery media that can increase the value of education for children. So that it is necessary that there is an Intractive CD device that can attract student motivation to learn and learning is very supportive to encourage students' curiosity towards learning, especially on the theme of caring about living with subthema I animals and plants in my home environment. 
Interactive CD-packed learning media is a very practical medium and can be used for learning and provide enthusiastic and as good as learners in their learning activities.

\section{METHOD}

This research method uses a type of development research that is often called Research and Development (R\&D). (Sugiono 2017) research and development is a research that is often used to produce products. Researchers conducted a study and developed a learning medium for elementary school learning with the theme of diversity in my country by using the development of ADDIE which is realized by five steps (Tegeh, Made jempel, i nyoman pudjawan 2014) as follows:

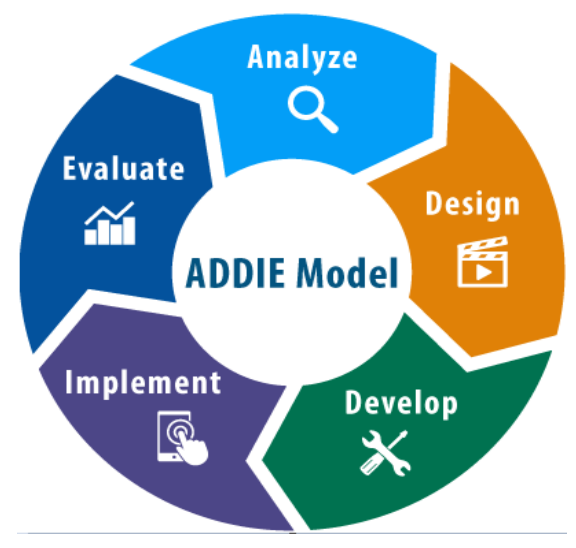

Figure 1: ADDIE MODEL

1. Stage I Analysis is the first stage in the ADDIE model that includes a. conducting competency analysis that must be obtained by learners; 2 . Analyze the characteristic peserta didik in his learning capacity; 3. Lysing the material according to competence

2. Stage II Design (Design) this second stage is designed with the following reference a. For Learners; 2. Competence; Strategy; 4 Assessment and evalusion. So in designing learning that is focused on three activities, namely choosing content that is in accordance with competence, strategies in learning that are applied and the form of evaluation used.

3. Phase III Development is the activity of woven specifications about design in physical form to produce a product that wants to be developed that collects all the content packaged into one.

4. Stage IV Implementation (Implementation) this stage for years whose influence on the quality of learning includes effectiveness, conservation and 
effective in learning. Products to be developed that make learners tertatik in learning can achieve the achievements achieved as expected.

5. Stage V Evaluation (Evalution) the last stage of the ADDIE model is a formative evaluation that isdone to collect data at each stage or step used to spur and evaluate thesumative in the end. This program is to find out its effect on learning outcomes and also the quality of learners' learning.

Test subjects in development research or $R \& D$ learning media based on Intractif CD with care for living things with animal and plant sub-themes in my home environment for class IV odd semester at State Elementary School 1 Kandang Situbondo consisting of 15 learners.

Research uses several supporting instruments in the study to get data on the validity, effectiveness and feasibility with the learning media of Intractive CDs which include observation sheets, sheetsanangket and tests.

To measure the results of presentations in validity, effectiveness and feasibility for intractive CD learning media using the formula:

$$
\text { Nilai }=\frac{\sum \text { skor Hasil }}{\sum \text { skor skor maksimal }} 100 \%
$$

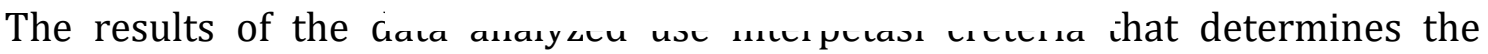
interpretation of the results of the analysis of the testponden data with the guidelines set by kereteria as follows:

Table 1: Interpretation criteria

\begin{tabular}{ccc}
\hline Category & Percentage & Qualification \\
\hline 4 & $86 \%-100 \%$ & Very Decent/ Effective \\
\hline 3 & $76 \%-85 \%$ & Decent/ Effective \\
\hline 2 & $56 \%-75 \%$ & Quite Decent/ Effective \\
\hline 1 & $<55 \%$ & Less Feasible/ Effective \\
\hline
\end{tabular}

(Sugiono, 2017)

\section{RESULTS AND DISCUSSIONS}

This research produces the product of learning media CD Intractif with the theme III Care for living things sub-theme I Animals and plants in my home environment for grade IV elementary / MI for the curriculum 2013 semester Odd.

In the first stage of analysis (Analyze) which does some important things, namely:

1. Analyze the competencies demanded for learners. Get maximum results in learning activities to complete learning. 
2. Analyze the characteristics of learners about learning capacityin terms ofknowledge, skills, and attitudes that are thought by learners

3. Perform analysis of material or content in accordance with the competencies that have beendetermined.

The second stage is Planning (Design) there are several important things that must be reviewed, among others:

1. Designing media for enthusiastic learners in learning activities.

2. Competencies taught to students to get maximum results.

3. Material (content) or skills according to being well studied.

4. Measure the freedom of learners with assessment and evaluation in learning.

The third stage, namely the development of learning media is development (Development) this stage is a development activity whose core is to translate the specifics of the physical form so as to produce the products it develops. This stage gathers the learning resources and references needed in developing material or content.

In the third stage of development in the form of physical or display learning media that can be used, in the media there are several buttons where the button there are learning objectives, Materials, Videos, help, close and Developer.

1. In the intro display there is the phrase "Welcome to SD Negeri 1 Kandang Kapongan Situbondo along with the logo tut turi handayani and play button to start

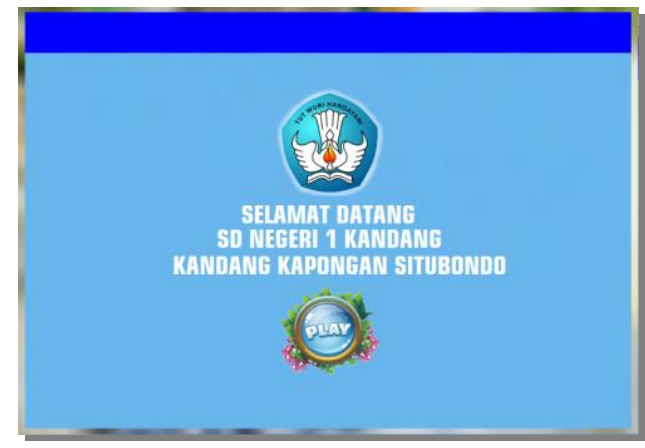

Figure 2: Initial view on the intro

2. On the second slide consists of several buttons that can be used music intrusion buttons, instructions for submission, competence, material, evalusion, developer refensi and close buttons to exit. 


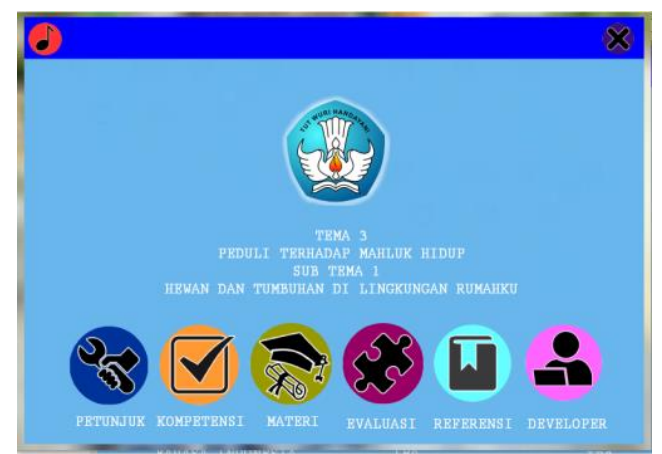

Figure 3: Main menu view

3. Display there is an instruction button for how to use media

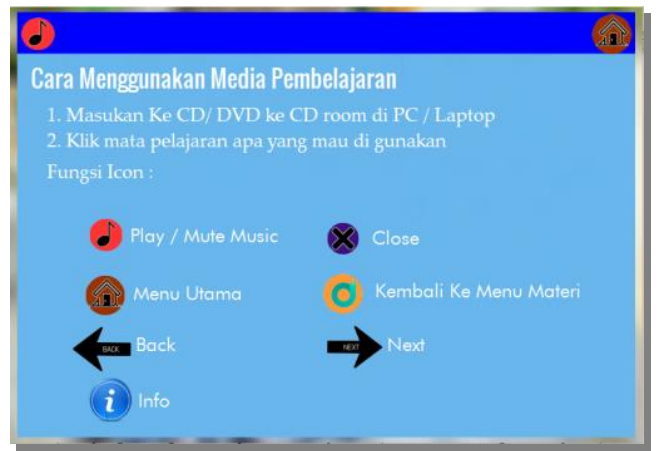

Figure 4: Instruction view

4. The fourth view is a competency consisting of 3 slides, namely inti competence,basic competencies and indicators.
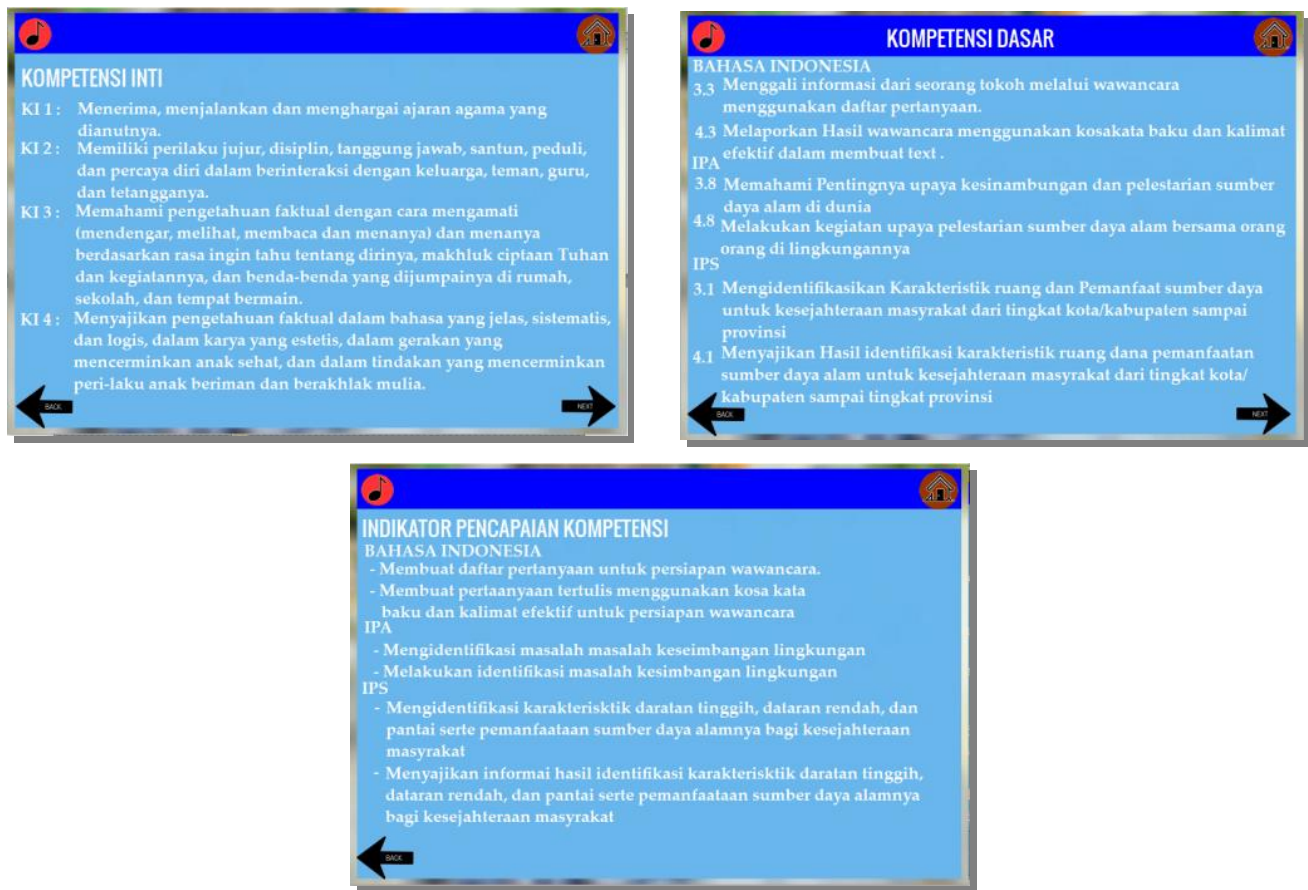

Figure 5: display of core competencies, basic competencies and indicators 
5. Display on the material slide there are 3 main buttons, including Indonesian, IPA and IPS
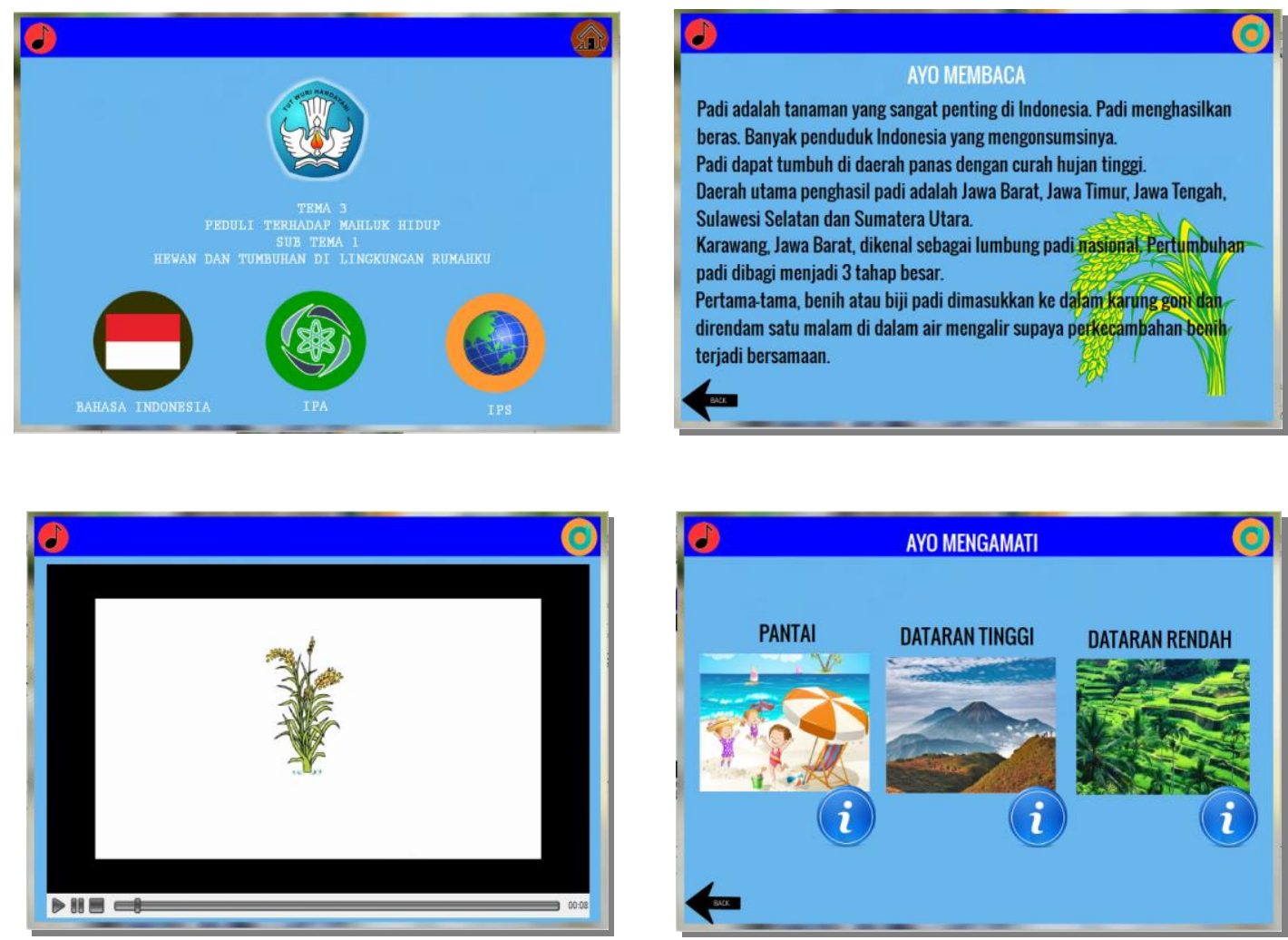

Figure 6: Display menu of Indonesian material, IPA and IPS

6. View on the evaluation button

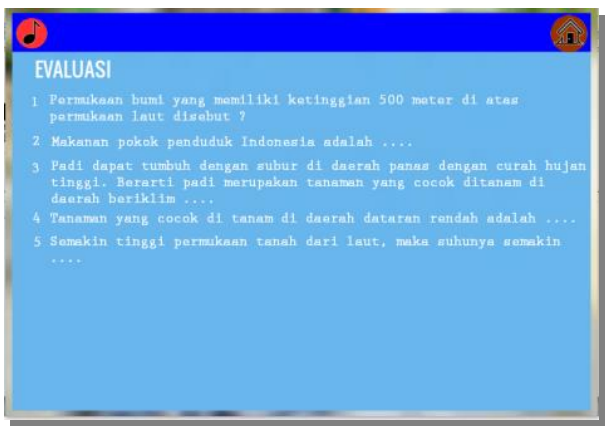

Figure 7: Evaluation of Learning 
7. On the view on the reference button

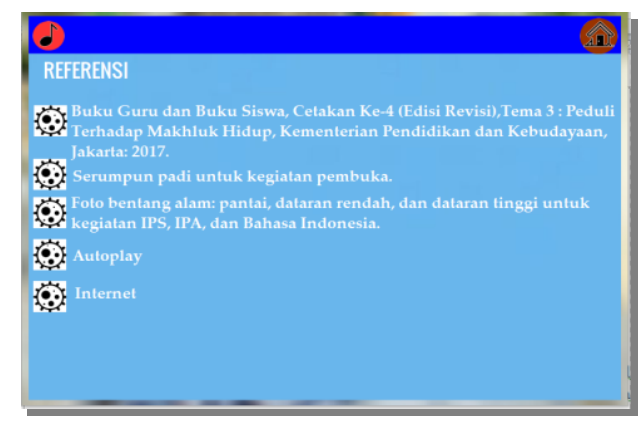

Figure 8 :Reflectivity View

8. On the view on the Developer button

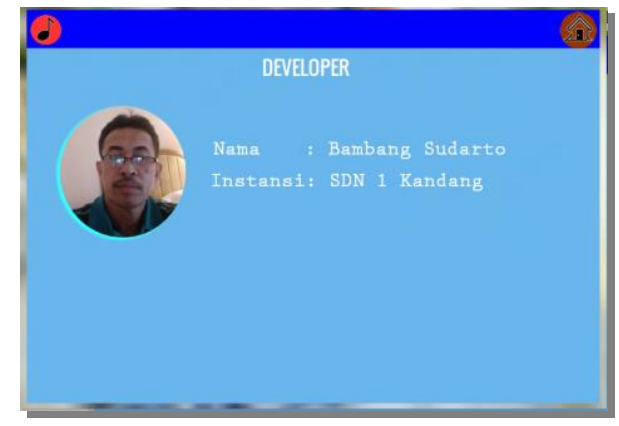

Figure 9: Delepor slide view

The fourth stage is implementasi (Implementation) is the result of the development applied in learning to find out whether there is an influence in learningagainst the quality of learning which includeseffectiveness, wisdom, practical and efficient in using the learning media of Ttraktif CD in learning.

The fifth stage is evaluation which includes formative and summative evalusion. Formative evaluation to obtain data at each stage is done to improve, while the summative evaluation is done at the end of the program to find out the extent of influence on learners' learning outcomes and the quality of learning using intractive CD-based learning media.

The results of validari expert material peneliti include aspects of content feasibility, presentation aspects, and language aspects of each aspect consisting of 11 questions whileforvalidation of Experts Madia Aspects of Kegrafik Feasibility there are several intikators that are in the value of media size, design, media content design, which consists of 23 questions. 
Table 2: Validation Results

\begin{tabular}{lc}
\hline Validation & \multicolumn{1}{c}{ Average } \\
\hline $\begin{array}{l}\text { Validation } \\
\text { Materials }\end{array}$ & $89,91 \%$ \\
\hline Media Validation & $86,95 \%$ \\
\hline
\end{tabular}

The results of the validation of material experts who arrange some of the aspects of content feasibility, Presentation and Language get a value of $89.91 \%$ which belongs to the quality group is very feasible. While the validation results of madia experts got a score of $86.95 \%$ which belongs to the qualification group is very feasible.

The results of the feasibility of the learning media of the intractive CD in the defense consisted of 15 learners with 11 questions with a maximum score of 44 scores per learner and while the number of all scores from 15 students 660 scores. Results from the eligibility of the media CD Intractif all students 574 Scores which with an average of $86.69 \%$ which is classified as a very decent qualification is calculated below

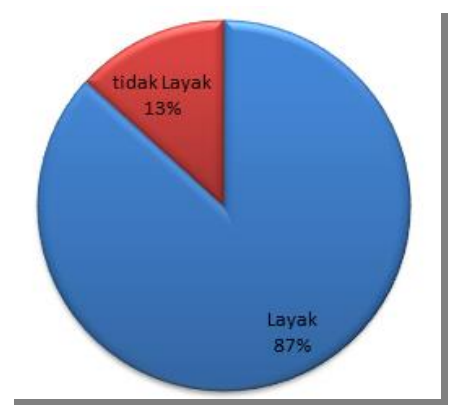

Figure 10: Due diligence results

While the results of the test of the effectiveness of the learning media of The Intractif CD in learning consisting of 15 respondents and 11 questions with a score of 44 per learner, and get a score of 567 with an average of $85.90 \%$ with classified qualifications are very worthy of yang in the presentation as below: 


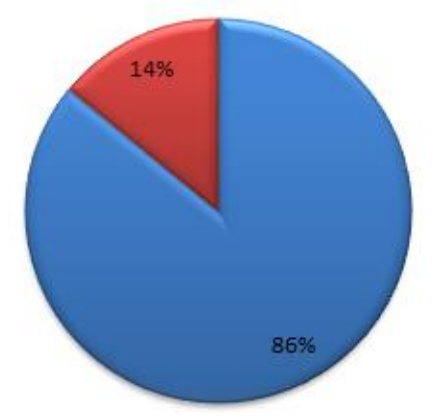

Figure 11: Effectiveness Test Results

The limited resistance of the development of ADDIE is to evaluate conducting trials on the ground by obtaining research in terms of practicality and effectiveness in the learning medium of Intractif CD

The following research results that have been validated by the material passed a score of $86.95 \%$ based on the classification assessed by material experts with 44 questions with a maximum score of 174 and get a score of 158 media development qualifications Are Very Feasible / Effective.

And the validation of material experts get a score of $89.91 \% \quad$ with 23 questions based on classification assessed by media experts with 23 Questions by getting a maximum score of 92 media development qualifications Are Very Feasible / Effective.

The purpose of learning media with the theme of caring about living things to facilitate the learning process in class for teachers to provide creativity in learning based on Intractive $\mathrm{CD}$ to become the goal of competence that has been established in choosing the media, evaluation of learning in learning activities at each stage with the development of the ADDIE model.

Learning media that arepacked withIntractif $C D$ has advantages as in the content of meteri there is music instruction, voice every click of a button, image, animation with diranacng bikto create learning activities to provide students with ease to get effective and efficient quality learning (Wahid et al. 2020).

It is also supported by the research presented by (Baehaqi et al., 2018)that the media uses Intractive CDs to provide a very accommodative, practical, effective and efficient medium.

\section{CONCLUSION}

Based on the results of the research developed that came to the following conclusions:

1. The stage of learning media development with Intractif $C D$ meets valid for the education of class VI SD Negeri 1 Kandang which is carried out development research procedures using the ADDIE development model, namely (1). Analiysis analyzes what is needed in school or in learning 
activities such as media. 2). Design Design (3). Development of product design realization. 4) Implemntation applies the product (5). Evalution evaluates finished products by measuring the ability of development goals.

2. Based on the instrument of eligibility of the learning media of The Intractif CD conducted by the study obtained an average score of $86.69 \%$ by entering the category of very worthy

3. Based on the effectiveness instrument carried out got an average score of 85.90\% which entered the eligible group.

\section{REFERENCES}

Baehaqi, I., Widiatsih, A., \& Atmaja, I. W. W. (2018). PENGEMBANGAN CD INTERAKTIF PADA MATA PELAJARAN MATEMATIKA MATERI KEKONGRUENAN DAN KESEBANGUNAN BANGUN DATAR KELAS IX SMP/MTs. Journal of Education Technology and Inovation, 1(2), 22-35. https://doi.org/10.31537/jeti.v1i2.173

Fajarisman, Asri Widiatsih, K. (2020). PENGEMBANGAN MEDIA PEMBELAJARAN BERBASIS ADOBE FLASH CS6 PADA MATA PELAJARAN BAHASA MANDARIN UNTUK SMP/MTs. 5(1), 1-16.

Kadek Suartama, I., Usman, M., Triwahyuni, E., Subiyantoro, S., Abbas, S., Umar, Hastuti, W. D., \& Salehudin, M. (2020). Development of E-learning oriented inquiry learning based on character education in multimedia course. European Journal of Educational Research, 9(4), 1591-1603. https://doi.org/10.12973/EU-JER.9.4.1591

Sugiono. (2017). Metode Penelitian \& Pengembangan (Reseach And Development) (ALFABETA (ed.); ke-3).

Tegeh, Made jempel, i nyoman pudjawan, K. (2014). Model Penelitian Pengembangan. GRAHA ILMU.

Wahid, A. H., Najiburrahman, Rahman, K., Faiz, Qodriyah, K., Hambali, El Iq Bali, M. M., Baharun, H., \& Muali, C. (2020). Effectiveness of Android-Based Mathematics Learning Media Application on Student Learning Achievement. Journal of Physics: Conference Series, 1594(1), 0-6. https://doi.org/10.1088/1742-6596/1594/1/012047 